\title{
EXPERIMENTAL STUDY ON THE PHYSICAL PROPERTIES OF MUD MORTAR IN COMPARISON WITH THE CONVENTIONAL MORTARS
}

\author{
Lekshmi M S ${ }^{1}$, Subha Vishnudas ${ }^{2}$ and Deepa G. Nair ${ }^{3}$ \\ 1,2,3 Division of Civil Engineering, School of Engineering, Cochin University of Science \\ and Technology, Kochi 682 022, Kerala State, India
}

\begin{abstract}
Mud is a versatile material which finds application in construction industry as mud blocks for wall construction, mud mortar for binding and plastering and as tiles for flooring and roofing. It is universally accepted as an environment friendly and user friendly material for construction from time immemorial. The state of Kerala, where nature imprints its heritage witnessed numerous mud constructions in the form of traditional buildings, ancient palaces and monumental buildings irrespective of the size of the buildings and status of the owners. Yet its utilization as a construction material has come down drastically over a past few decades with the advent of cement and concrete. In a state like Kerala, where there is ample scope for procuring mud, it is high time that its potential as building material has been fully utilized. The potential of mud as a sustainable building material has been overviewed by the same authors in the first phase of investigation. As the second phase experimental work was conducted to compare the properties of mud mortar with conventional mortars so as to check the feasibility of using mud as mortar. The effect of stabilizers such as cow dung, cement and lime on raw mud has been studied in this paper. This paper also checks the effect of fibres on the durability of reinforced mud mortar.
\end{abstract}

\section{KEYWORDS}

Mud mortar, Cement mortar, Lime mortar, Cow dung, Waste coir mat fiber

\section{INTRODUCTION}

Mud had proved to be an excellent material for construction in the form of mud bricks and earthen plasters from time immemorial, ever since man started his life on earth. Around 58 percent of all buildings in India today are made of mud brick, and among them some are as many as 50 to 100 years old [1]. Earthen plasters are typically mixed on-site and consist of local clayrich soil, sand water and chopped straw. They have been successfully used for centuries but are still viewed with some scepticism by the common man [2]. Not much scientific literature pertaining to the parameters that affect the strength and durability of the earthen plasters are available. Hence past few decades witnessed a drastic transformation from earthy to ash coloured concrete buildings. The poor acceptance of mud constructions may be attributed to some sociocultural and technological factors also. In order to create proper awareness among the people about the durability of mud constructions a detailed experimental study was found necessary. This paper is an attempt to compare the physical properties of mud mortar with those of the conventional cement and lime mortars and to check the feasibility of using mud as mortar. The effect of traditional stabilizers such as cow dung and that of conventional stabilizers such as cement and lime has been analysed in the experimental study. This paper also deals with the possibility of incorporating fibers such as waste coir mat fibers in enhancing the durability of mud mortar. 


\section{Mud Mortar - A RevieW}

Dry mud is a composition of soil particles of varying sizes. When water of required quantity is added, it becomes mud mortar of proper consistency. The constituents of mud mortar are sand $(2 \mathrm{~mm}-0.075 \mathrm{~mm}$ size $)$, silt $(0.075 \mathrm{~mm}-.002 \mathrm{~mm}$ size $)$, clay $(<0.002 \mathrm{~mm}$ size $)$ and water $(30-35 \%$ by weight). The conventional stabilizers used for mud were cement and lime. While cement mortars gave greater strength and durability, lime mortars gave better finish to the walls. Reddy, et al., (2006) investigated the compressive strengths and elastic properties of stabilised mud mortar masonry using cement mortar, cement-lime mortar and cement-soil mortars and came to the conclusion that an increase in cement content of a cement-soil mortar from $10 \%-15 \%$ results in about $20 \%$ increase in the masonry compressive strength [3]. A study conducted on the compressive strength characteristics of cement stabilised rammed earth walls by Jayasinhe, et al., (2007) indicate that laterite soils stabilised with about $6 \%$ cement can be used as a wall material for single storey houses in tropical climatic conditions [4].

One of the drawbacks of mud mortar is the occurrence of shrinkage cracks on drying. Several studies have shown that incorporation of fibres into the soil matrix increases the durability of soil matrix by reducing the cracks. Fibers increase the cohesion among the soil particles while the interaction of the fibers among themselves and the fibers flexibility makes them behave as a structural mesh that holds the soil together [5]. In Ghana mud mortars have, traditionally, been improved by the addition of organic matter such as cow dung and ashes from agro processing waste [6]. Sreekumar, et al., (2012) found in his study that the addition of $0.5 \%$ of coir industry waste resulted in about $20 \%$ increase of the compressive strength of stabilized lateritic blocks [7].

\section{Materials ANd Methods}

The materials used for this study consists of locally available soil; cement, lime and cow dung as stabilizers; coir waste as fibrous materials and water as lubricant.

\subsection{Material Characterisation}

Soil : The soil sample for the study was collected from Chovvara, Aluva in Ernakulam district from a depth of $60 \mathrm{~cm}$ below the ground level. It was subjected to field tests (color test, touch and smell test, bisuit test, hand wash test, cigar test, lustre test and adhesion test) at the site itself and laboratory tests ( $\mathrm{pH}$, organic content, specific gravity, grain size distribution and atterberg limits) to determine the properties. The results of material characterisation of soil are tabulated in Table 1.

Cement : The cement used was OPC 43 grade cement.

Lime : Lime shells were procured from a local dealer and then it was wetted by sprinkling water on their pile. This mix was kept wet overnight. Then the mixture was crushed by grinding and sieved through $90 \mathrm{~mm}$ sieve. This lime was then stored with protection from moisture in plastic bags.

Cow dung: The cow dung was obtained from a local subsistence farmer and dried in the sun and crushed for use.

Fibres : Waste Coir fibre (WCF) were collected from a coir mat industry at Alappuzha, Kerala. The properties of the fibre are recorded in the Table 2. The waste coir mat was washed and dried prior to use. The coir was cut to lengths less than $5 \mathrm{~cm}$ to avoid balling of fibres. $0.5 \%$ of fibres 
were added because too much of fibres affect the engineering properties of the soil. The fibres were randomly oriented. During the mixing the fibres were added by hand in stages to get a homogeneous matrix. Mixing was continued to get a uniform distribution of fibres throughout the matrix, without aggregation of the fibres which will result in congestion and conglomeration of the matrix.

Table 1. Properties of soil

\begin{tabular}{|c|c|c|c|}
\hline Sl no. & Property & Result & $\begin{array}{c}\text { Remarks } \\
\text { (standard values) }\end{array}$ \\
\hline 1 & Color & $\begin{array}{c}\text { Reddish } \\
\text { orange }\end{array}$ & $\begin{array}{c}\text { Suitable for mud } \\
\text { construction }\end{array}$ \\
\hline 2 & $\mathrm{pH}$ & 6.387 & $\begin{array}{c}5.9-6.5 \text { (moderately acidic) } \\
{[9]}\end{array}$ \\
\hline 3 & Organic content & $0.075 \%$ & $<0.5 \%$ (low organic content) \\
[9]
\end{tabular}

Table 2. Physical and chemical properties waste coir fiber [7]

\begin{tabular}{|c|l|c|l|}
\hline \multicolumn{2}{|c|}{ Physical } & \multicolumn{2}{c|}{ Chemical } \\
\hline Diameter & $0.32 \mathrm{~mm}$ & Lignin & $39.62 \%$ \\
\hline Density & $1.35 \mathrm{~g} / \mathrm{cc}$ & Cellulose & $22.99 \%$ \\
\hline Tenacity & 14.85 & Ash & $2.99 \%$ \\
\hline $\begin{array}{c}\text { Breaking } \\
\text { elongation }\end{array}$ & $26.53 \%$ & Pectin & $2.40 \%$ \\
\hline Swelling in water & $88.35 \%$ & & \\
\hline
\end{tabular}

\subsection{Tests on Mortar}

The experimental study includes determination of compressive strength, water absorption and linear shrinkage. The mix proportion and designation of mortar samples are shown in Table 3. Nine cube samples were prepared for each proportion. 
Table 3 Designation of mortar samples

\begin{tabular}{|c|c|c|c|c|c|c|c|c|c|}
\hline Designation & $M$ & C & $\mathbf{L}$ & MC5 & ML4 & MCD10 & MCD20 & MCF & MLF \\
\hline $\begin{array}{l}\text { Description } \\
\text { of mix } \\
\text { proportion } \\
\text { (by weight) }\end{array}$ & $\begin{array}{l}\text { Mud } \\
\text { mortar }\end{array}$ & $\begin{array}{l}\text { Cement } \\
\text { mortar } \\
(1: 5)\end{array}$ & $\begin{array}{l}\text { Lime } \\
\text { mortar } \\
(1: 2)\end{array}$ & $\begin{array}{l}\text { Mud + } \\
5 \% \\
\text { cement }\end{array}$ & $\begin{array}{l}\text { Mud } \\
+4 \% \\
\text { lime }\end{array}$ & $\begin{array}{l}\text { Mud + } \\
10 \% \\
\text { cow } \\
\text { dung }\end{array}$ & $\begin{array}{l}\text { Mud + } \\
20 \% \\
\text { cow } \\
\text { dung }\end{array}$ & $\begin{array}{l}\text { MC5 } \\
+ \\
0.5 \% \\
\text { WCF }\end{array}$ & $\begin{array}{l}\text { ML4+ } \\
0.5 \% \mathrm{WCF}\end{array}$ \\
\hline $\begin{array}{l}\text { Water } \\
\text { content }(\%)\end{array}$ & 42 & 10.5 & 16.5 & 27 & 32 & 30 & 34 & 27 & 32 \\
\hline
\end{tabular}

\subsubsection{WET COMPRESSIVE STRENGTH TEST}

The mud mortar samples were tested according to IS $2250-1981$. Three samples each were used for testing compressive strength at the end of $7^{\text {th }}$ day and $28^{\text {th }}$ day of curing. Cement mortar cubes were demoulded after 24 hours of casting and immersed in curing tank for 28 days. Lime mortar cubes were demoulded after 72 hours of casting and left in air for four days. At the end of 7 days lime mortar cubes were immersed in curing tank. Hence 28 day strength alone is taken for lime mortar cubes. Mud mortar samples were given gunny bag curing for 28 days.

\subsubsection{WATER ABSORPTION TEST}

This test was carried out according to the IS: 1725 - 1997. In this three specimens of each combination were dried in a ventilated oven at a temperature of 105 to $115^{\circ} \mathrm{C}$ till attain constant mass and noted it's mass. Completely dried blocks were then immersed in clean water for 24 hours and noted the new mass. The average difference of masses was expressed in percentage.

\subsubsection{LINEAR SHRINKAGE TEST}

The linear shrinkage of mortar samples were determined using linear shrinkage apparatus. It is a rectangular box of inner dimensions $25 \mathrm{~cm} \mathrm{x}\left(\mathrm{L}_{1}\right) 2.5 \mathrm{~cm}$ x. $1.5 \mathrm{~cm}$. The inside surface of the box was greased to prevent the soil from sticking to the walls. Mortar sample was prepared using the required water content. It was then filled into the apparatus by proper compaction and neatly smoothened off with the spatula so that the sample exactly fills the mould (Fig. 1a). This was then left as such in the shade for 14 days. The length of the sample after 14 days was measured $\left(\mathrm{L}_{2}\right)$ (Fig. 1b). The difference in length is expressed in percentage of the initial length to get the percentage linear shrinkage.

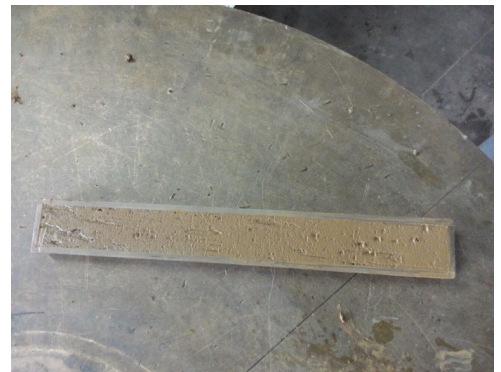

Fig. 1a. Raw mud mortar sample

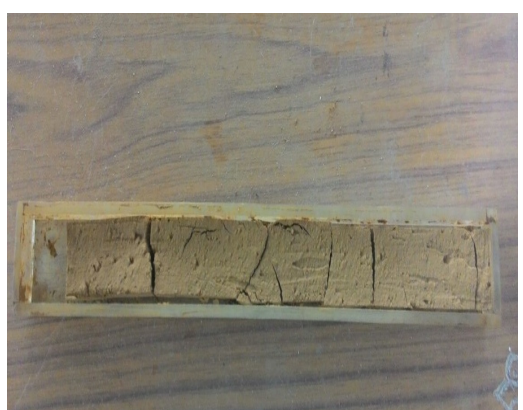

Fig. 1b. Linear shrinkage (14 days) 


\section{RESUlts AND Discussions}

To check the physical properties, mortar samples were tested for compressive strength, water absorption and linear shrinkage. The results of compressive strength, water absorption and linear shrinkage of the different mixes are presented in this section. The linear shrinkage test was conducted on M, MC5, MC20, MCF and MLF samples.

\subsection{COMPRESSIVE STRENGTH}

The compressive strength of the tested nine samples are presented in graph (Fig. 2.) It is observed from the graph that raw mud without stabilisation has got a 28 day compressive strength of $4 \mathrm{~N} / \mathrm{mm}^{2}$ which is two times more than the recommended value of $2 \mathrm{~N} / \mathrm{mm}^{2}$ as per IS $2250-1981$. Conventional cement mortar (1:5) has the highest 28 day compressive strength of $21.93 \mathrm{~N} / \mathrm{mm}^{2}$. The compressive strength of conventional lime mortar (1:2) was found to be $1.561 \mathrm{~N} / \mathrm{mm}^{2}$ which is the lowest among the tested samples. Mud mortar stabilized with 5\% cement had a compressive strength of $2.07 \mathrm{~N} / \mathrm{mm}^{2}$ which is less than that of raw mud. The percentage of water for preparing mortar was selected arbitrarily for maintaining adequate workability of the mortar samples: for raw mud mortar and mud mortar stabilized with 5\% cement are $42 \%$ and $27 \%$ respectively. Curing was done using gunny bags for all combinations of mud mortar. The reason for decrease in compressive strength in cement stabilization may be due to the lack of proper hydration of cement. Hence it requires further experimental study.

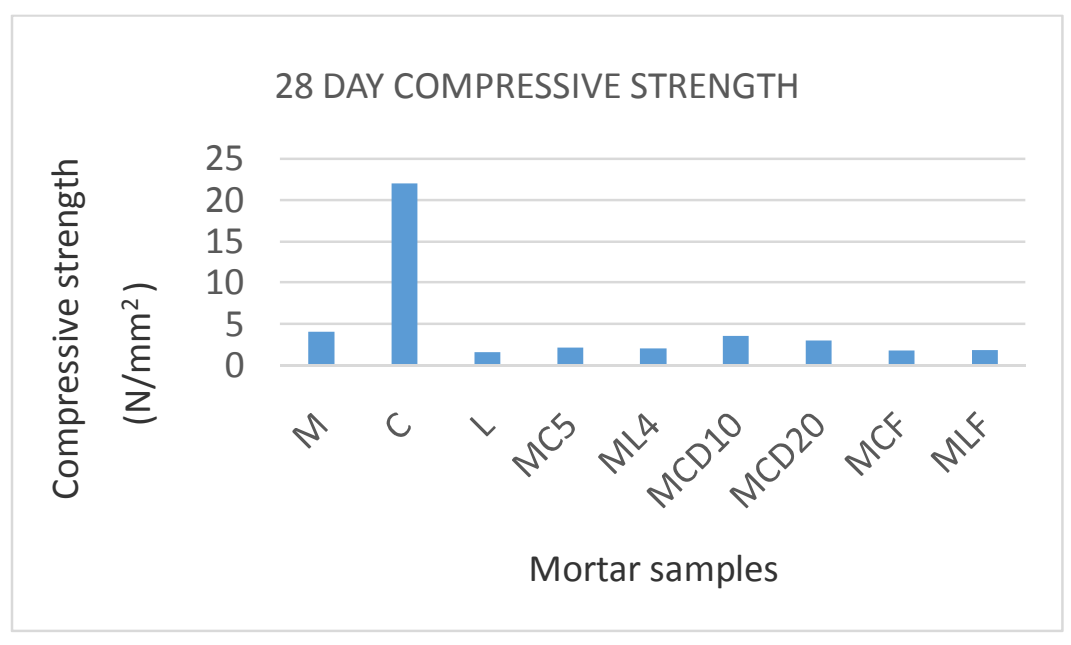

Fig. 2 Compressive strength of mortar samples

The mud mortar stabilised with $10 \%$ cow dung got a compressive strength $\left(3.534 \mathrm{~N} / \mathrm{mm}^{2}\right)$ comparable to that of the raw mud mortar whereas that stabilised with $20 \%$ cow dung showed a decrease in compressive strength from $3.188 \mathrm{~N} / \mathrm{mm}^{2}$ (7 day) to $2.916 \mathrm{~N} / \mathrm{mm}^{2}$ ) 28 day. This decrease in compressive strength may be due to the increased fiber content in the cow dung. In the case of fiber reinforced mortar the mud mortar stabilized with $4 \%$ lime $\left(1.834 \mathrm{~N} / \mathrm{mm}^{2}\right)$ and $0.5 \%$ WCF had more compressive strength than that with $5 \%$ cement $\left(1.667 \mathrm{~N} / \mathrm{mm}^{2}\right)$ but the values were less than the recommended values for required for masonry mortar. 


\subsection{WATER ABSORPTION}

The percentage water absorption of all samples are plotted in the graph (Fig. 3). The raw mud sample, mud mortar stabilized with $10 \%$ and $20 \%$ cow dung got completely disintegrated in water when subjected to water absorption test. This justifies the need for proper stabilisation of mud mortar. Good mortar mixes have water absorption well below $10 \%$ by mass [10]. Conventional cement mortar samples has got the lowest value for water absorption (8.76\%) when compared with other samples. Lime mortar sample showed $15.5 \%$ water absorption. The mortar samples stabilised with 5\% cement (26.44\%) and 4\% lime (28.45\%) had comparable percentage water absorption. The incorporation of $0.5 \% \mathrm{WCF}$ fibres resulted in a slight increase in the percentage water absorption in both the mixes. As the fibre content increases the homogeneity of the mix will be decreased and it will become more porous.

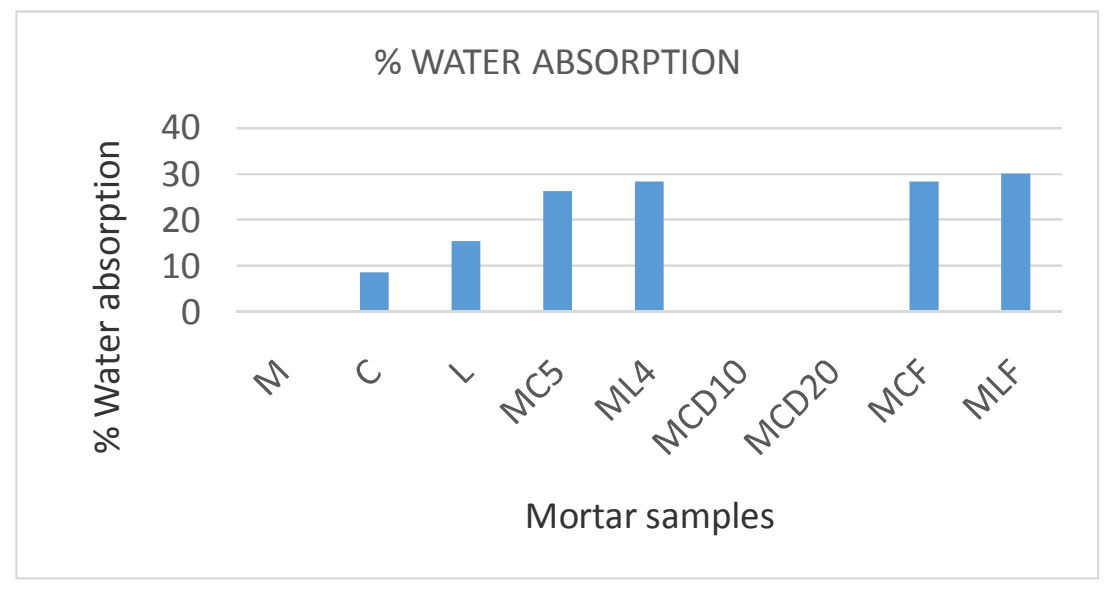

Fig. 3. Water absorption of mortar samples

\subsection{LINEAR SHRINKAGE}

New Zealand standard 4298 (1998) suggests 3\% as the limit for linear shrinkage of earth mortars [11]. Among the five mortar samples tested, the lowest linear shrinkage was reported in mud mortar stabilized with 5\% cement and reinforced with $0.5 \%$ waste coir fibre $(2.43 \%)$ causing a reduction in linear shrinkage to about $75 \%$ when compared with that of the raw mud mortar sample $(9.49 \%)$. Stabilization of mud mortar with $20 \%$ cow dung alone is found to decrease the shrinkage cracks by $50 \%$ giving a linear shrinkage of $(4.74 \%)$ which can be observed from the graph (Fig. 4). Mud mortar stabilized with 5\% cement showed a linear shrinkage of $3.162 \%$ causing a reduction of linear shrinkage by $66.6 \%$. 
Civil Engineering and Urban Planning: An International Journal (CiVEJ) Vol.3, No.2, June 2016

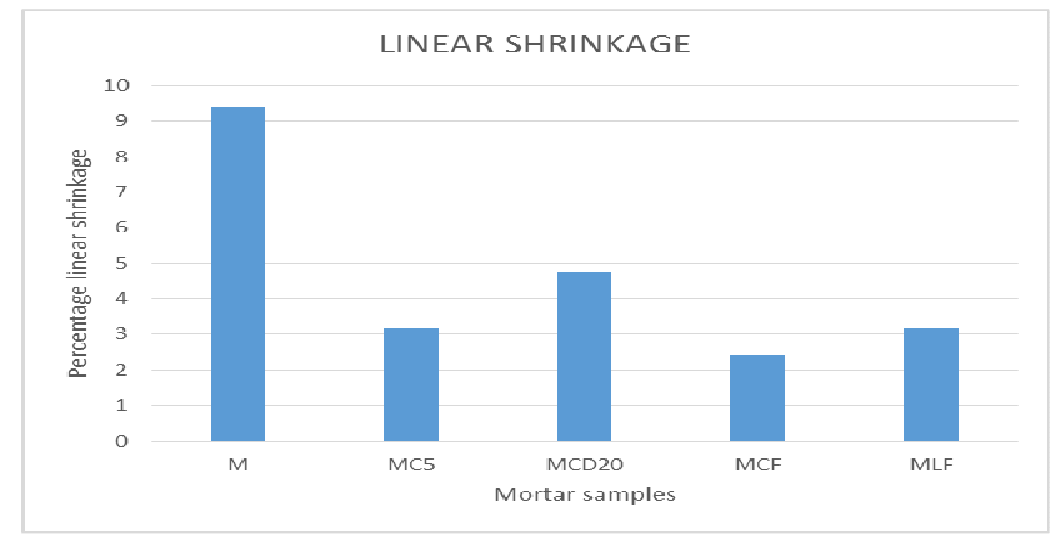

Fig. 4. Linear shrinkage of mortar samples

\section{CONCLUSiON}

The conclusions drawn from the study on mud mortar specific to the characteristics of the materials used and the range of parameters investigated are summarized below.

1. The virgin mud mortar proposed in this study had adequate compressive strength. But the durability was found inferior as it was found susceptible to water penetration and had appreciable linear shrinkage cracks.

2. In mud mortar stabilized with $5 \%$ cement the linear shrinkage was reduced by $66 \%$, compressive strength was found to be $50 \%$ as that of virgin mud mortar, but adequate as per the standards $\left(2.07 \mathrm{~N} / \mathrm{mm}^{2}\right)$ and water absorption was $26 \%$.

3. In mud mortar stabilized with $5 \%$ cement and $0.5 \% \mathrm{WCF}$, linear shrinkage was reduced by $75 \%$, compressive strength was found to be less than the accepted standards $(1.667 \mathrm{~N} /$ $\mathrm{mm}^{2}$ ) and water absorption was $28 \%$.

Since there is variation in results with respect to each of the physical properties tested, the paper concludes by the remark that it is feasible to use the selected soil sample as mortar for construction subjected to the following experimental measures.

(i) Increasing the percentage of cement to $8 \%$

(ii) Decreasing the percentage of fibre to $0.25 \%$

\section{ACKNOWLEDGEMENTS}

The authors would like to thank everyone for their valuable advices and support in carry out the work successfully.

\section{REFERENCES}

[1] Mudscape Housing, August 9, 2011 Available From: openarchitecture network. Org /projects/9960 (Accessed on April 4, 2014)

[2] Ashour, T., Bahanasawey, A and Wei Wu (2010), "Compressive strength of fibre reinforced earth plasters for straw bale buildings", Australian Journal of Agricultural Engineering, Vol. 1, No. 3, pp.86-92. 
[3] Reddy, B.V.V, and Ajay Gupta, (2006), "Strength and elastic properties of stabilized mud block masonry using cement-soil mortars", Journal of materials in civil engineering, Vol. 18, No. 3 pp. 472-476.

[4] Jayasinhe, C. and Kamaladasa, N. (2007) "Compressive strength characteristics of cement stabilized rammed earth walls", Construction and Building Materials, Vol. 21, No. 11, pp.1971-1976.

[5] Sivkumar Babu, G. .L and Vasudevan, A. K.(2008), "Strength and stiffness response of coir fiber reinforced tropical soil", Journal of Materials in Civil Engineering, Vol 20, No.9 pp. 571-577.

[6] Peter Paa-Kofi Yalley and Dorothy Manu (2013), "Strength and durability properties of cow dung stabilized earth bricks", Civil and Environmental Research, Vol. 3, Issue 13, pp.117-125

[7] Sreekumar, M. G., and Nair, D.G., (2013), "Stabilized lateritic blocks reinforced with fibrous coir wastes”, Int.J. of Sustainable Construction Engineering \& Technology, Vol 4, No. 2, pp. 23-32.

[8] IS codes : IS: 2250-1981, IS: 13077-1991, IS 2720 (Part III/ Sec 2) - 1980, IS:2720 (Part 4) -1985, IS: 2720 (Part 5) - 1985, IS: 2720 (Part 6), IS:2720 (Part 22)-1972 , IS:2720 (Part 26) -1987 and IS:6932 (Part VII)-1973

[9] Methods Manual - Soil Testing in India (January 2011), Department of Agriculture and Cooperation, Ministry of Agriculture, Govt. of India New Delhi

[10] Gingos, G.S., and Mohammed Sutan, N., (2011), “Effect of PFA on compressive strength and water absorption of mortars, UNIMAS e-journal of Civil Engineering, March 2011, Vol. 2, No. 1, pp. 7-11, Available (online), Accessed on Dec 10, 2015, http://www.feng.unimas.my/ujce/images/article/Volume2Issue1Mac2011/2Vol2Issue1.pdf

[11 ]Mileto, C., Vegas, F., and Cristini V., (), Rammed earth conservation, Proceedings on the first International Conference on Rammed Earth Conservation, Restapia, Valentia, Spain, June 21-23, 2012 , CRC Press, Taylor and Francis Group, Balkema, Leiden, The Netherlands, pp. 643-644 .

\section{Authors}

\section{Short Biography}

Lekshmi M. S. took her B.Tech. Degree in Civil Engineering (2000) and M.Tech. Degree (2002) in Hydraulics Engineering from University of Kerala, India. She has more than 13 years of teaching experience and has worked in four reputed engineering colleges in Kerala, India. Currently she is working as Asst. Professor in Division of Civil Engineering, Schoolof Engineering, Cochin University of Science and Technology, India and pursuing her parttime Ph.D. under the same university. Her areas of interests are

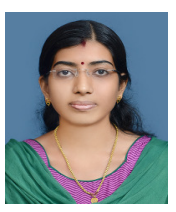
Hydraulics engineering, geotechnical engineering and sustainable building materials. She is a Life member of Indian Society of Technical Education (ISTE) and an associate member of Institution of Engineers, India (IEI). She has attended several national and international seminars, conferences and workshops and has presented papers in national and international journals and conferences. In addition she has chaired and cochaired national and international seminars.

\section{Subha Vishnudas}

She graduated with a B.Tech. in Civil Engineering from Mahatma Gandhi University, India in 1991 and took her Master's Degree form Kerala University in 1995. She attained Ph.D from Delft University of Technology, Netherlands in 2006. She has more than 16 years of teaching experience and has published about 28 research publications in International journals and conferences. She has visited many foreign countries like USA, Germany etc. for presenting research papers in International conferences. She has

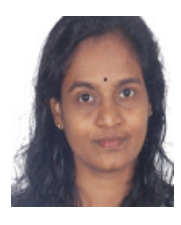
also delivered many invited talks and also chaired and co-chaired national and international conferences and is also a reviewer of several international journals and conferences. In addition she has professional membership in many technical bodies like IGS, ISTE, NCMRI (Trivandrum), ISSE and EWRA. Presently she is guiding about 6 research fellows for the Ph.D programme while working as Asso. Professor in the Division of Civil Engineering, School of Engineering, CUSAT. 
Civil Engineering and Urban Planning: An International Journal (CiVEJ) Vol.3, No.2, June 2016

\section{Deepa G. Nair}

She graduated with a B.Tech. Degree in Civil Engineering from Kerala University (1992) and took her Masters in Habitat Technology from BITS, Pilani (1995). She attained Ph.D from Delft University of Technology, Netherlands in 2006. She has more than 15 years of teaching experience and 5 years of industrial experience. Her areas of interests are sustainable building materials and affordable housing. She has published about 24 research publications in international journals and conferences. She has visited many foreign countries like Spain, Tokyo etc., for presenting research papers in International conferences. She has delivered many invited talks and chaired and co-chaired national and international conferences. In addition she has got professional membership in many technical bodies like ISTE, IEI etc. Presently she is guiding about 9 research fellows for Ph.D programme while working as Asso. Professor, Division of Civil Engineering, School of Engineering, CUSAT, India. 